\title{
Gene Transfer of Prostaglandin Synthase Maintains Patency of the Newborn Lamb Arterial Duct
}

\author{
TILMAN HUMPL, SYED H.E. ZAIDI, JAMES Y. COE, JENNIFER RUSSELL, YASUFUMI KANEDA, \\ HAMID MASSAELI, LEE N. BENSON, AND MARLENE RABINOVITCH
}

\begin{abstract}
Department of Pediatrics [T.H., J.R.. L.N.B.], Division of Cardiology, Cardiovascular Research [S.H.E.Z., H.M., M.R.], Research Institute, University of Toronto, The Hospital for Sick Children, Toronto, Ontario M5G 1X8, Canada; Department of Pediatrics [J.Y.C.], Division of Pediatric Cardiology, University of Alberta, Edmonton, Alberta T6G 2B7, Canada; Division of Gene Therapy Science [Y.K.], Osaka
\end{abstract}

University, Osaka 565-0871, Japan

\begin{abstract}
In congenital heart disease with left- or right-sided obstruction, prostaglandin $\mathrm{E}(\mathrm{PGE})_{1}$ or $\mathrm{PGE}_{2}$ is infused to maintain ductus arteriosus (DA) patency. We hypothesized that transfection of the DA with PGE synthase would lead to a greater production of $\mathrm{PGE}_{2}$ in situ and, hence, patency of the DA. The cDNA for human prostaglandin synthase was sequenced and ligated into a eukaryotic expression vector. The negative control was created by ligating the cDNA encoding the bacterial protein chloramphenicol acetyltransferase into the same plasmid. Transfection (600 $\mu \mathrm{g}$ DNA) was achieved in lambs within the first $24 \mathrm{~h}$ of life using the hemagglutinating virus of Japan (HVJ)liposome transfection method with a custom-made, basketweave-perforated catheter. Echocardiography was performed to assess DA patency until the time of sacrifice. To confirm expression of the transgene, $\mathrm{PGE}_{2}$ concentration was measured in organ culture of the DA by immunoassay and by Western immunoblotting of homogenized DA tissue. Patency of the DA was demon-
\end{abstract}

\section{ABSTRACT}

strated by color Doppler in all the lambs (7/7) in which the PGE synthase was delivered, whereas functional closure was seen in the control group (6/6). The $\mathrm{PGE}_{2}$ concentration in the culture medium of the explanted DA in the treatment group was 3-fold higher than that of the control groups. Western immunoblotting confirmed the presence of PGE synthase in the treatment group. Gene transfer of PGE synthase to the DA is feasible and will maintain patency for at least $1 \mathrm{wk}$. (Pediatr Res 58: 976-980, 2005)

\section{Abbreviations}

CAT, chloramphenicol acetyltransferase

DA, ductus arteriosus

ET-1, endothelin-1

HVJ, hemagglutinating virus of Japan

$\mathbf{P G E}_{2}$, prostaglandin $\mathrm{E}_{2}$
In congenital heart disease with left- or right-sided obstruction, $\mathrm{PGE}_{1}$ (alprostadil) or $\mathrm{PGE}_{2}$ (dinoprostone) is infused to maintain patency of the DA. Although the DA produces endogenous $\mathrm{PGE}_{2}(1)$, the dilatory capacity of this compound decreases with time due to the accelerated production of the vasoconstrictor ET-1 (2) in response to oxygen (3) and the reduced expression of $\mathrm{PGE}_{2}$ receptor(s) $(4,5)$. However, prolonged PGE infusion is problematic as a result of tachyphylaxis and major side effects, including respiratory depression, which

Received September 28, 2004; accepted April 5, 2005.

Correspondence: Marlene Rabinovitch, M.D., Stanford University School of Medicine CCSR-2245 B, 269 Campus Dr., Stanford, CA 94035162; e-mail: marlener@ stanford.edu Supported by a grant from the Canadian Institutes of Health Research MT723 and from the Martin Foundation through the Hospital for Sick Children Foundation. M.R. is an endowed chair of the Heart and Stroke Foundation of Ontario and a Distinguished Scientist of the Canadian Institutes of Health Research MT 723.

Current address for M.R.: Department of Pediatrics and, by courtesy, Developmental Biology, Stanford University School of Medicine, Stanford, CA.

DOI: 10.1203/01.PDR.0000182820.20333.2A may require mechanical ventilation, systemic hypotension, bradycardia, irritability, fever, lethargy, gastric-outlet obstruction, and hyperostosis (6-10).

This study was carried out to determine that local expression of $\mathrm{PGE}_{2}$ could be achieved through percutaneous gene transfer (11) of PGE synthase (EC5.3.99.3) (12). Using a custom-made catheter positioned in the DA, enzyme expression was sufficient to prevent closure of the DA. Local administration of the plasmid was achieved using liposomes conjugated to the HVJ, as previously described. We confirmed patency of the DA and selective expression of $\mathrm{PGE}_{2}$ in $\mathrm{DA}$ tissues harvested at $7 \mathrm{~d}$ after birth.

\section{METHODS}

Cloning of PGE synthase cDNA and preparation of the vector construct. The cDNA for PGE synthase (12) was not available and, therefore, cloning of the full-length cDNA was undertaken. Total RNA was isolated from human fetal aortic smooth muscle cells using RNeasy Mini kit (QIAGEN, Mississauga, ON, Canada). Following the instructions of the manufacturer, cells were 
harvested and centrifuged at $300 \times g$ for 5 min, then disrupted using a buffer with $\beta$-mercaptoethanol. Homogenization was achieved by passing the lysate five times through a $20-\mathrm{G}$ needle fitted to a syringe; $70 \%$ ethanol was added and the mixture was centrifuged at $8500 \times g$. After washing and elution, the RNA was collected in RNase-free water, followed by reverse transcription with SuperScriptII reverse transcriptase and $0.5 \mu \mathrm{g}$ Oligo(dT) $(3,5,13-17)$ primer in accordance with the manufacturer's instructions (Invitrogen, Burlington, ON, Canada). PGE-synthase cDNA was amplified using a forward 22SC (5'-TGCCCACAGCCTGGTGATGA-3') and a reverse 23SC primer (5'-AGCTGGCAGACACTTCCATTTA-3'). PCR was carried out under the following conditions: $94^{\circ} \mathrm{C}$ for $4 \mathrm{~min}$ followed by 35 cycles of denaturation at $94^{\circ} \mathrm{C}(1 \mathrm{~min})$, annealing at $68^{\circ} \mathrm{C}(1 \mathrm{~min})$, and extension at $72^{\circ} \mathrm{C}(1 \mathrm{~min})$. An additional primer extension step was performed at $72^{\circ} \mathrm{C}$ for $1 \mathrm{~min}$. The PCR product was gel purified and additional $5^{\prime}$ and $3^{\prime}$ nucleotide sequences were added by PCR using a forward H3 (5'-GAATTCGGCACGAGGGAGATGCCT-3') and a reverse K1 primer (5'-GAGGTGCTGGGCCCAGCTGGCAGACACTTCC-3'). Primers $\mathrm{H} 3$ and $\mathrm{K} 1$ contained nine nucleotides at the $5^{\prime}$ end with the recognition sequences for HindIII and $K p n I$, respectively, to facilitate later cloning into the pcDNA3 vector. The PCR conditions were the same as described above, except that annealing was performed at $64^{\circ} \mathrm{C}$. The PCR product was then ligated into the pGEM-T vector (Promega, Madison, WI), sequenced, and subcloned into the pcDNA3 plasmid (Invitrogen, Carlsbad, CA) at HindIII/KpnI restriction sites. As a control, pcDNA3 carrying the bacterial CAT gene ligated into the HindIII/KpnI site was used. Large-scale plasmid DNA preparations were performed using EndoFree Plasmid Maxi Kit (QIAGEN). Glyercol stocks were also prepared and stored frozen at $-70^{\circ} \mathrm{C}$ for later use.

Transfection of aortic smooth muscle cells to verify gene expression. Human fetal aortic smooth muscle cells were grown from explants in Medium 199 (Wisent Inc., St. Bruno, QC, Canada) containing 10\% fetal bovine serum and $1 \%$ antibiotics/antimycotics at $37^{\circ} \mathrm{C}, 5 \% \mathrm{CO}_{2}$ in a humidified tissue culture incubator as previously described. At confluence, cells at passage 2 were used for the transient transfection experiments. This was achieved using SuperFect reagent (QIAGEN). Briefly, $2.5 \mu \mathrm{g}$ of plasmid DNA PGE 2 synthase or the CAT control were dissolved in a total volume of $150 \mu \mathrm{L}$ of Medium 199 (Wisent Inc.) containing no serum, proteins, or antibiotics. Then, $12.5 \mu \mathrm{L}$ of SuperFect reagent were added to the DNA solution and $500 \mu \mathrm{L}$ of growth media containing serum and antibiotics were added to the smooth muscle cells cultured in six-well plates. To determine whether $\mathrm{PGE}_{2}$ was effectively generated after transfection with the PGE synthase containing plasmid, the supernatant was harvested $24 \mathrm{~h}$ after transfection. The concentration of $\mathrm{PGE}_{2}$ was measured using a commercial immunoassay (R \& D Systems, Minneapolis, $\mathrm{MN}$ ) using a microplate reader measuring absorbance at $405 \mathrm{~nm}$ with wavelength correction set between 570 and $590 \mathrm{~nm}$ (Versmax, Molecular Devices, Menlo Park, CA).

Gene transfer with HVJ-liposomes-HVJ-liposome preparation. The preparation of the HVJ-liposomes has been described previously in detail (18).

Delivery catheter. To facilitate direct gene transfer into the DA, a catheter was designed with a basket tip tailored to the size of the DA of a newborn lamb (Fig. 1). The basket was made of nitinol tubing and consisted of four tubes with four laser-burned microperforations in each tube on the outer surface (Memry Corp., Bethel, CT) mounted on an abridged 4F right coronary catheter (Judkins type, Cordis, Miami, FL). The flexibility of the tubing allowed it to be
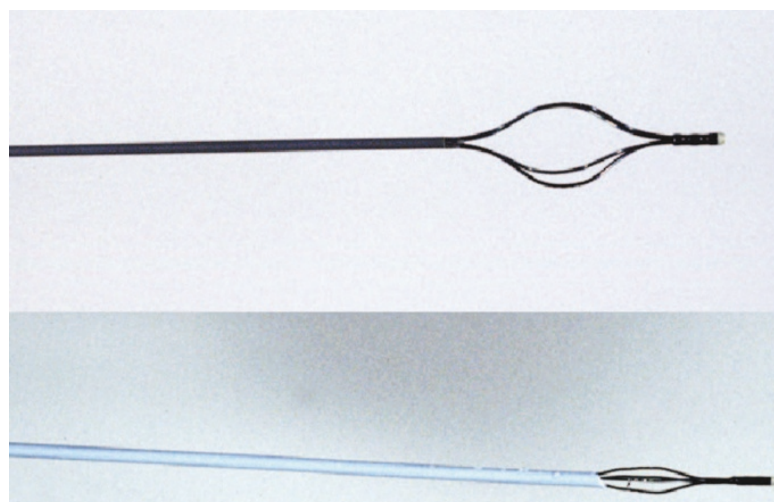

Figure 1. Nitinol catheter. Top shows basket expanded. Bottom shows basket collapsed in the guiding catheter. compressed when introduced into a $5 \mathrm{~F}$ guiding catheter (Zuma, Metronic AVE, Danvers, MA). The basket was opened in the pulmonary artery, with optimal expansion of the basket into the DA. The delivery basket was nonocclusive, thus flow through the DA was maintained during gene transfer.

Animal experiment. All experiments were performed under a protocol approved by the Animal Care Committee of The Hospital for Sick Children and in accordance with the guidelines of the American Physiologic Society. The newborn lambs were brought to the animal catheterization laboratory within the first $24 \mathrm{~h}$ of life and randomly assigned to receive gene transfer with $\mathrm{PGE}_{2}$ (mean weight, $5 \mathrm{~kg}$; range, $\left.3.1-6.21 \mathrm{~kg}\right)(n=7)$ or as a control to receive gene transfer of CAT (mean weight, $4.7 \mathrm{~kg}$; range, $3.5-5.25 \mathrm{~kg})(n=$ 6). Animals were intubated and ventilated. General anesthesia was maintained with oxygen ( $4 \mathrm{~L} / \mathrm{min})$, nitrous oxide $(2 \mathrm{~L} / \mathrm{min})$, and halothane $(0.75-1.00 \%)$ : 500,000 IU of penicillin $\mathrm{G}$ were given intramuscularly at the beginning of the procedure as a precaution against infection. Percutaneous access to the femoral artery was achieved with a 6F Desilets-Hoffman introducer set (Cook Inc., Bloomington, IN). A guidewire (Terumo Glidewire, 0.035 in, Terumo Corp., Tokyo, Japan) was directed into the pulmonary artery via the patent DA under direct single-plane fluoroscopy. The guiding catheter was then placed in the DA and the wire removed. The custom-made delivery catheter, flushed with normal saline solution, was attached with a two-way stopcock and positioned in the DA, with the basket against the vessel wall. Then, $1.2 \mathrm{~mL}$ of the HVJ-liposome-DNA mixture was injected three times into the DA wall, while rotating the basket. Catheters and sheaths were removed, and the newborn lambs extubated and returned to the ewes after local bleeding was controlled.

After a 48-h recovery period, the lambs underwent color and pulsed Doppler echocardiographic studies to assess the patency status of the DA. These examinations were repeated every $2 \mathrm{~d}$. The animals underwent a final study on $\mathrm{d} 7$ or 9 after the procedure as determined by availability of staff, and were killed by an overdose of sodium pentobarbital ( $2.7 \mathrm{~g} / \mathrm{animal})$. At that time, the group that received gene transfer with $\mathrm{PGE}_{2}$ had a mean weight of 7.7 $\mathrm{kg}$ (range, 4.7-9.4 kg), whereas the control group had a mean weight of $7.3 \mathrm{~kg}$ (range, $5.4-8.3 \mathrm{~kg})(p=0.28)$, reflecting a similar mean weight gain. Although the focus of these exams was on the flow through the DA, cardiac function, at least qualitatively, did not appear impaired.

Morphologic and biochemical analyses of DA tissue. The DA was rapidly excised, periadventitial fat removed, and the tissue divided into two rings, one for $\mathrm{PGE}_{2}$ assay and the other for histologic analysis to verify patency. To assay $\mathrm{PGE}_{2}$ production from the organ culture, one ring of DA tissue was kept on a collagen gel (6.4 mL Vitrogen, (Cohesion Technologies, Palo Alto, CA), 0.8 $\mathrm{mL} 10 \times$ PBS, $0.8 \mathrm{~mL} 0.1 \mathrm{M} \mathrm{NaOH}$ ) in $35-\mathrm{mm}$ dishes containing $1 \mathrm{~mL}$ Medium 199 (Wisent Inc.) plus 10\% fetal bovine serum and 1\% antibiotics/ antimycotics at $37^{\circ} \mathrm{C}$ for $24 \mathrm{~h}$. Another ring of DA tissue to be used for Western immunoblot detection of $\mathrm{PGE}_{2}$ was snap frozen in liquid nitrogen and stored at $-70^{\circ} \mathrm{C}$. To confirm DA patency by histology, fixation with $10 \%$ formalin by perfusion at $70 \mathrm{~mm} \mathrm{Hg}$ was carried out. The vessels were maintained under this pressure for $24 \mathrm{~h}$ and placed in fresh fixative overnight before embedding in paraffin. Five-micrometer tissue sections were stained by the hematoxylin-eosin method. The number of cells in the arterial media in three random visual fields using a Leica DC500 microscope (Leica Microsystems AG, Wetzlar, Germany) were counted at $40 \times$ magnification.

Western immunoblot analysis. To assay PGE synthase by Western immunoblot, DA tissues were homogenized in $400 \mu \mathrm{L}$ potassium phosphate buffer $(0.1 \mathrm{M}, \mathrm{pH} 7.4)$ and sucrose $(0.25 \mathrm{M})$. The samples were frozen on dry ice and sonicated three times for $20 \mathrm{~s}$ (Polytron, Brinkmann Homogenizer Model PT $10 / 35$, Kinematica, Basel, Switzerland). After centrifugation at $1,000 \times g$ for $10 \mathrm{~min}, 10,000 \times \mathrm{g}$ for $15 \mathrm{~min}$, and $170,000 \times g$ for $1 \mathrm{~h}$ at $4^{\circ} \mathrm{C}$, the pellets were resuspended in $150 \mu \mathrm{L}$ of the potassium phosphate homogenization buffer and lyophilized to achieve a higher yield. Total protein concentration was determined (Bio-Rad, Hercules, CA). For Western immunoblot analyses, protein extracts $(30 \mu \mathrm{g}$ ) were boiled for 2 min and equally loaded on a 4-20\% Novex polyacrylamide gel (Invitrogen, Carlsbad, CA) and transferred to a nitrocellulose membrane (Bio-Rad) under nonreducing conditions. Blots were blocked overnight at $4{ }^{\circ} \mathrm{C}$ in Tris-buffered saline (TBST) containing nonfat dry milk and Tween-20 (Fisher Biotech, Fair Lawn, NJ). After washing in TBST, incubation with the primary (anti-PGE synthase polyclonal antibody, Cayman Chemical, Ann Arbor, MI, dilution 1:350) for 60 min and with the $2^{\circ}$ antibody (anti-rabbit, Amersham Pharmacia Biotech UK, Ltd., Little Chalfont, Buckinghamshire, UK, dilution 1:7500) for 45 min was carried out. The blots were washed again and developed using Renaissance chemiluminescence reagent (PerkinElmer Life Science, Boston, MA).

Statistical analysis. Data were analyzed by ANOVA followed by Duncan's test to determine which groups were different. A $p$ value $<0.05$ was considered statistically significant. 


\section{RESULTS}

$P G E_{2}$ expression-cell culture. To test the production of functional PGE synthase, human aortic smooth muscle cells were transfected with a construct carrying the cDNA for human PGE synthase. Immunoassay established that the concentration of $\mathrm{PGE}_{2}$ in the supernatant of the human aortic smooth muscle cells transfected with PGE synthase constructs was 2.3 times higher than in cells transfected with the control CAT constructs ( $p=0.0001)$ (Fig. 2A).

Echocardiographic examination of the DA. Serial Doppler echocardiography, performed every second day until d 7 or 9 of life, revealed patency of the DA in all seven lambs in which the PGE synthase was delivered, whereas functional closure was documented by $48 \mathrm{~h}$ in each of the six control animals in which CAT was delivered (Fig. 3). The narrowest diameter of the DA was $4.4 \mathrm{~mm}$ (range, $4.0-4.9 \mathrm{~mm}$ ) at the first exam and $3.6 \mathrm{~mm}$ (range, $2.9-4.0 \mathrm{~mm}$ ) at the end of the study period.

Necropsy examination of the DA. Formalin fixation of the DA (with a perfusion pressure of $70 \mathrm{~mm} \mathrm{Hg}$ ) confirmed patency without alterations in intimal cushions in the PGE synthase-transfected lambs, whereas the DA was closed in the control (CAT-transfected) group (Fig. 4, $A$ and $B$ ).

There was no significant difference in cell density in the media of DA from PGE synthase $(87+11$ cells per field $)$ and CAT control $(82+10$ cells per field $)$ transfected animals $(p=$ $0.2)$.

$P G E_{2}$ expression-organ culture. To examine $\mathrm{PGE}_{2}$ production, DA tissues were harvested $7 \mathrm{~d}$ after transfection with the PGE synthase or CAT constructs and placed in the organ culture for $24 \mathrm{~h}$. The concentration of $\mathrm{PGE}_{2}$ in the supernatant was three times higher than in the DA tissues from animals transfected with the control CAT construct $(p=0.0001)$ (Fig. $2 B)$.

Western immunoblotting. To confirm the PGE synthase protein production in the transfected DA tissues, Western immunoblot was performed using anti PGE synthase antibod-

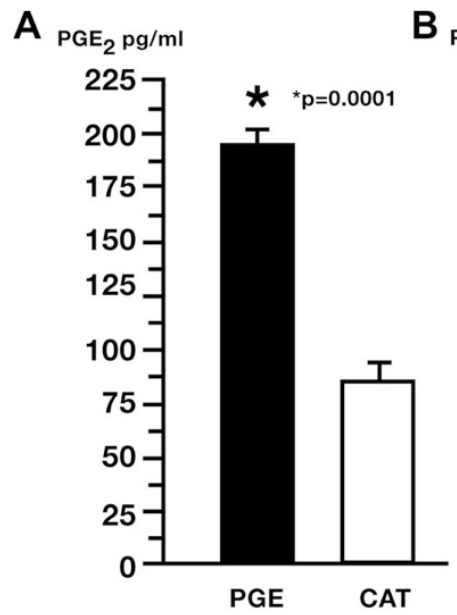

$\mathrm{B}_{\mathrm{PGE}_{2} \mathrm{pg} / \mathrm{ml}}$

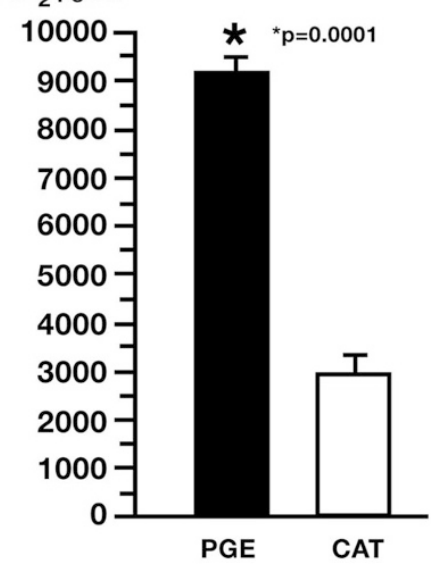

Figure 2. (A) $\mathrm{PGE}_{2}$ concentration in the supernatant of cultured aortic smooth muscle cells after transfection with PGE synthase or with the CAT construct. Bars represent mean $\pm \operatorname{SEM}(n=6)$ for each group. $(B) \mathrm{PGE}_{2}$ concentration in the supernatant of cultured DA smooth muscle cells after transfection of the animals with PGE synthase $(n=6)$ or with the CAT construct $(n=5)$. Bars represent mean $\pm \mathrm{SEM}$.

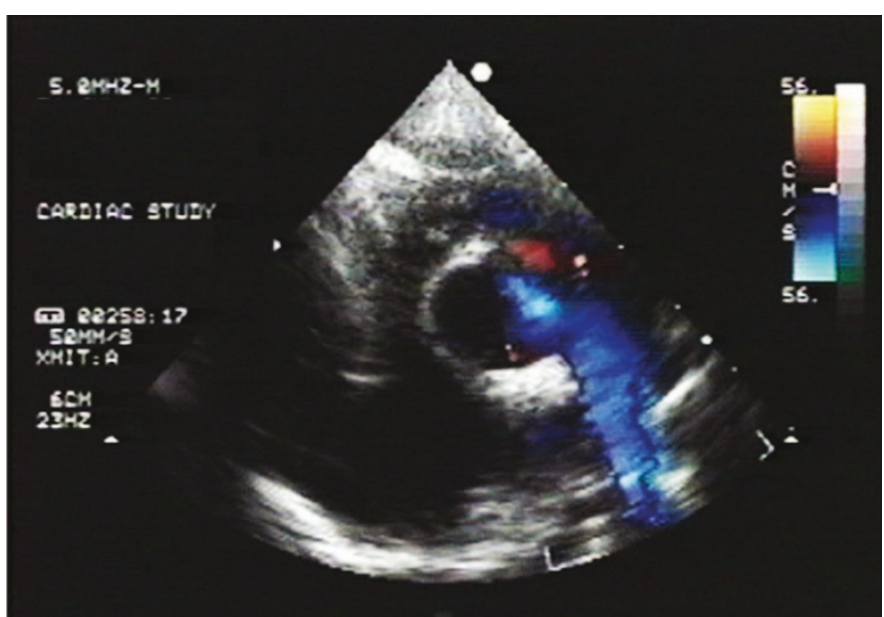

Figure 3. Echocardiogram with color Doppler on an animal transfected with PGE synthase, $7 \mathrm{~d}$ after the procedure. Modified short axis. The red color indicates the flow through the DA toward the pulmonary arteries.
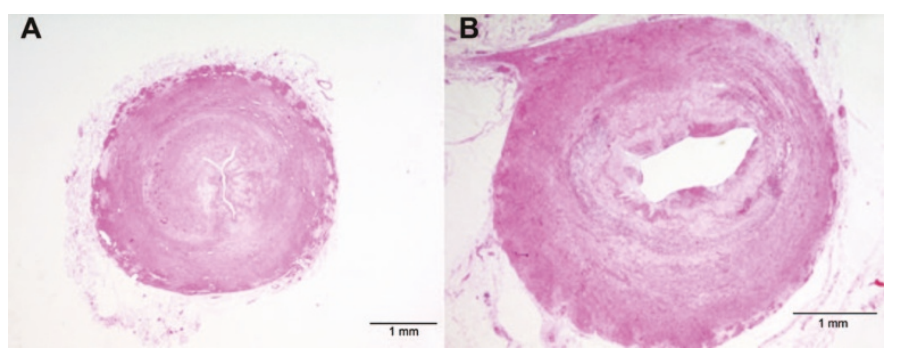

Figure 4. (A) Cross-section of a DA transfected with the CAT construct. The lumen is slitlike and the DA is functionally closed. (B) Cross-section of a DA transfected with the PGE synthase. The lumen is open with intimal cushion formation. Magnification $\times 2.5$.

ies. PGE synthase expression was only observed in the DA of PGE-synthase-transfected but not in the control CATtransfected animals (Fig. 5).

Mild changes of increased respiratory rate were noticed in the PGE synthase-treated lambs but anticongestive treatment was not necessary. There were no overt manifestations of labored breathing, apnea, or feeding intolerance.

\section{DISCUSSION}

The results of our study show the efficacy of gene transfer of PGE synthase to maintain anatomical and histologic patency of the DA and the production of $\mathrm{PGE}_{2}$ by the tissue. This represents the first successful gene transfer to maintain patency of the DA in the newborn animal and underscores the possibility

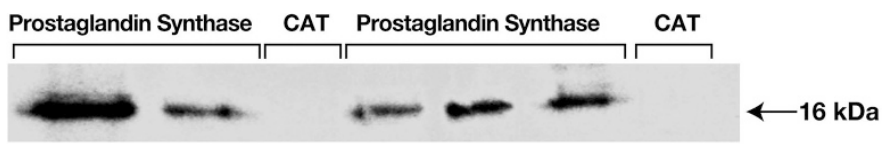

Figure 5. Western immunoblotting of transfected DA tissues. The band size of $16 \mathrm{kD}$ indicates PGE synthase expression observed in all five lambs in which it was assayed following transfection of the PGE synthase construct; no signal is detected in tissues from the two lambs that were transfected with the CAT control vector. 
that local production of $\mathrm{PGE}_{2}$ may obviate the morbidity and toxic systemic side effects associated with intravenous PGE therapy.

Previous studies by our group have shown the efficacy of gene therapy administered directly into the fetal lamb DA to inhibit the formation of intimal cushions and maintain patency of the DA in the early postnatal period (19). Clinical application of that strategy has two drawbacks. First, the approach is invasive, and, second, it requires a fetal ultrasound diagnosis of a DA-dependent congenital heart lesion.

The management of a duct-dependent congenital heart lesion often requires infusion of $\mathrm{PGE}_{2}$ to maintain ductal patency, with inherent side effects. These are particularly problematic with long-term use, in the infant in which heart transplantation seems the most viable surgical option. Limited patency of the DA achieved through local expression of prostaglandin might allow for the natural drop in pulmonary vascular resistance over time, stable arterial saturations and the possibility of reducing surgical procedures.

In our study, a clear difference in the expression of $\mathrm{PGE}_{2}$ and PGE synthase between the two experimental groups was observed. However, one caveat should be considered in the interpretation of these results: cell viability might be different between the two groups because cell death frequently follows ductus closure in full-term lambs. Therefore, some of the observed differences in production of $\mathrm{PGE}_{2}$ might be due to differences in cell viability between the two groups of 7-d-old ductus. Nevertheless, transfection of the PGE synthase was associated with a significant delay in ductus arteriosus closure after birth.

The feasibility of gene transfer requires the manufacture of a catheter optimally designed to deliver the gene locally without obstructing ductal flow. Different models of catheters have been used for local intravascular drug delivery (13,20-22): the Dispatch spiral balloon catheter, microporous catheters, the double balloon catheter, and hydrogel-coated catheters with passive diffusion as the mechanism of application. Needle or porous catheters operate for local drug delivery, through a mechanism of creating a pressure gradient by injection (16). The custom-made catheter in this study was tailored to the size of the DA of a newborn lamb, and so allowed optimal contact with the vessel wall and delivery of the compound without obstructing blood flow to the DA. This is a prerequisite for use in children with duct-dependent congenital heart lesions. The average systolic arterial pressure in the newborn lamb is 58 $\mathrm{mm} \mathrm{Hg}$, compared with a systolic pulmonary artery pressure of $40 \mathrm{~mm} \mathrm{Hg} \mathrm{(23).} \mathrm{This} \mathrm{may} \mathrm{have} \mathrm{produced} \mathrm{some} \mathrm{spill-over} \mathrm{of}$ the HVJ-liposome-DNA mixture into the systemic circulation, but no side effects were detected.

Unfortunately, the application of "naked" DNA in vivo has a very low efficiency, and recombinant viruses are commonly used for gene transfer. These are viruses with some or all of the viral genes replaced by the relevant therapeutic gene. To date, the three most commonly used viruses for gene transfer are adenovirus, retrovirus, and adeno-associated virus. The advantage of high efficiency with these viruses is attenuated by significant immunologic and cytotoxic complications. The inflammatory responses induced by adenovirus particles can be intense and potentially fatal. In this regard, a recent insertional mutagenesis event was reported as a significant risk associated with retroviral-mediated gene transfer (24).

To determine feasibility of our approach, we applied a method of gene transfer previously demonstrated by our group to be efficacious (19). The encapsulation of DNA in lipid membranes fused with UV-inactivated HVJ improves its incorporation and cellular transport (14). HVJ-liposomes are highly efficient vehicles for the introduction of oligonucleotides into cells as well as for the transfer of genes $<100 \mathrm{kbp}$ without damaging cells. However, the transient expression of genes delivered in this way and the lack of selectivity are still limitations to this approach (25). It is of interest that a higher expression level of $\mathrm{PGE}_{2}$ was observed in the tissues after transfection than in the cell culture studies. Newer modalities such as ultrasound may help in the delivery of genes to target vascular tissues (26).

Several enzymatic pathways may contribute to $\mathrm{PGE}_{2}$ metabolism, but their actions in the regulation of $\mathrm{PGE}_{2}$ levels in vivo and their role in the events that lead to the remodeling of the DA after birth are unknown. Endogenous prostaglandins are synthesized from arachidonic acid by COX via the unstable prostaglandin intermediate $\mathrm{PGH}_{2}$, which, in turn, is converted into other prostaglandin species such as $\mathrm{PGE}_{2}$ by the action of specific prostaglandin synthases. Two COX isoforms, COX-1 and COX-2, are found in both endothelial and smooth muscle cells of the DA, although there is dispute about the primary location for each $(27,28)$. Among different mammalian species there are changes in expression of these enzymes in the preand postnatal periods $(17,29)$. The HVJ-liposomes penetrate the media and intima of the DA, where circulating $\mathrm{PGE}_{2}$ is produced $(5,30,31)$.

There is some uncertainty about the vasoconstrictive impact of ET-1 on the DA. Coceani et al. $(2,32)$ reported that oxygeninduced constriction depends on the synthesis and release of ET-1, whereas Fineman et al. (15) suggest that the substance has a minor role in closure of the DA at birth.

We performed no measures to exclude systemic and other toxicity-related effects of the gene therapy approach. This will, of course, be necessary before considering the safety as well as the efficacy of this approach in patients.

In conclusion, in the present study it was possible to maintain DA patency for up to $9 \mathrm{~d}$ before closure was becoming evident by turbulence on the color Doppler images. This may be related to diminishing production of PGE as well as to changes in the prostaglandin receptor profile (33).

Acknowledgment. The authors thank Cameron Slorach, Echo Technologist, Hospital for Sick Children, Toronto, Ontario, Canada, for technical assistance during echocardiography of the animals.

\section{REFERENCES}

1. Rabinovitch M, Boudreau N, Vella G, Olley PM1987 Prostaglandin synthesis in fetal ductus arteriosus pulmonary artery and aorta endothelial and smooth muscle cells. Pediatr Res 21:A-387

2. Coceani F, Kelsey L, Seidlitz E 1992 Evidence for an effector role of endothelin in closure of the ductus arteriosus at birth. Can J Physiol Pharmacol 70:1061-1064 
3. Coceani F, Liu Y, Seidlitz E, Kelsey L, Kuwaki T, Ackerley C, Yanagisawa M 1999 Endothelin A receptor is necessary for $\mathrm{O}(2)$ constriction but not closure of ductus arteriosus. Am J Physiol 277:H1521-H1531

4. Clyman RI, Mauray F, Roman C, Heymann MA, Payne B 1983 Factors determining the loss of ductus arteriosus responsiveness to prostaglandin E. Circulation 68:433436

5. Coceani F, Olley PM 1988 The control of cardiovascular shunts in the fetal and perinatal period. Can J Physiol Pharmacol 66:1129-1134

6. Babyn P, Peled N, Manson D, Dagan O, Silver MM, Koren G 1995 Radiologic features of gastric outlet obstruction in infants after long-term prostaglandin administration. Pediatr Radiol 25:41-43

7. Heymann MA, Clyman RI 1982 Evaluation of alprostadil (prostaglandin E1) in the management of congenital heart disease in infancy. Pharmacotherapy 2:148-155

8. Kramer HH, Sommer M, Rammos S, Krogmann O 1995 Evaluation of low dose prostaglandin E1 treatment for ductus dependent congenital heart disease. Eur J Pediatr 154:700-707

9. Lewis AB, Freed MD, Heymann MA, Roehl SL, Kensey RC 1981 Side effects of therapy with prostaglandin E1 in infants with critical congenital heart disease Circulation 64:893-898

10. Peled N, Dagan O, Babyn P, Silver MM, Barker G, Hellmann J, Scolnik D, Koren G 1992 Gastric-outlet obstruction induced by prostaglandin therapy in neonates. N Eng J Med 327:505-510

11. Tanner FC, Carr DP, Nabel GJ, Nabel EG 1997 Transfection of human endothelial cells. Cardiovasc Res 35:522-528

12. Jakobsson PJ, Thorén S, Morgenstern R, Samuelsson B 1999 Identification of human prostaglandin E synthase: a microsomal, glutathione-dependent, inducible enzyme, constituting a potential novel drug target. Proc Natl Acad Sci U S A 96:7220-7225

13. Dick A, Kromen W, Jüngling E, Grosskortenhaus S, Kammermeier H, Vorwerk D, Günther RW 1999 Quantification of horseradish peroxidase delivery into the arteria wall in vivo as a model of local drug treatment: comparison between a porous and a gel-coated balloon catheter. Cardiovasc Intervent Radiol 22:389-393

14. Dzau VJ, Mann MJ, Morishita R, Kaneda Y 1996 Fusigenic viral liposome for gene therapy in cardiovascular diseases. Proc Natl Acad Sci U S A 93:11421-11425

15. Fineman JR, Takahashi Y, Roman C, Clyman RI 1998 Endothelin-receptor blockade does not alter closure of the ductus arteriosus. Am J Physiol 275:H1620-H1626

16. Flugelman MY, Jaklitsch MT, Newman KD, Casscells W, Bratthauer GL, Dichek DA 1992 Low level in vivo gene transfer into the arterial wall through a perforated balloon catheter. Circulation 85:1110-1117

17. Guerguerian AM, Hardy P, Bhattacharya M, Olley P, Clyman RI, Fouron JC, Chemtob S 1998 Expression of cyclooxygenases in ductus arteriosus of fetal and newborn pigs. Am J Obstet Gynecol 179:1618-1626

18. Kaneda Y 1994 Virus (sendai virus envelopes)-mediated gene transfer. In: Celis JE (ed) Cell Biology: A Laboratory Handbook. Academic Press, San Diego, pp 50-57

19. Mason CA, Bigras JL, O'Blenes SB, Zhou B, McIntyre B, Nakamura N, Kaneda Y, Rabinovitch M 1999 Gene transfer in utero biologically engineers a patent ductus arteriosus in lambs by arresting fibronectin-dependent neointimal formation. Nat Med $5: 176-182$

20. Alfke H, Wagner HJ, Calmer C, Klose KJ 1998 Local intravascular drug delivery: in vitro comparison of three catheter systems. Cardiovasc Intervent Radiol 21:50-56

21. Baumbach A, Herdeg C, Kluge M, Oberhoff M, Lerch M, Haase KK, Wolter C, Schröder S, Karsch KR 1999 Local drug delivery: impact of pressure, substance characteristics, and stenting on drug transfer into the arterial wall. Catheter Cardiovasc Interv 47:102-106

22. Wolinsky H, Thung SN 1990 Use of a perforated balloon catheter to deliver concentrated heparin into the wall of the normal canine artery. J Am Coll Cardio $15: 475-481$

23. Ibe BO, Hibler S, Raj JU 1998 Platelet-activating factor modulates pulmonary vasomotor tone in the perinatal lamb. J Appl Physiol 85:1079-1085

24. Hacein-Bey-Abina S, von Kalle C, Schmidt M, Le Deist F, Wulffraat N, McIntyre E, Radford I, Villeval JL, Fraser CC, Cavazzana-Calvo M, Fischer A 2003 A serious adverse event after successful gene therapy for X-linked severe combined immunodeficiency. N Engl J Med 348:255-256

25. Kaneda Y, Saeki Y, Morishita R 1999 Gene therapy using HVJ-liposomes: the best of both worlds? Mol Med Today 5:298-303

26. Lawrie A, Brisken AF, Francis SE, Cumberland DC, Crossman DC, Newman CM 2000 Microbubble-enhanced ultrasound for vascular gene delivery. Gene Ther 7:2023-2027

27. Clyman RI, Hardy P, Waleh N, Chen YQ, Mauray F, Fouron JC, Chemtob S 1999 Cyclooxygenase- 2 plays a significant role in regulating the tone of the fetal lamb ductus arteriosus. Am J Physiol 276:R913-R921

28. Coceani F, Ackerley C, Seidlitz E, Kelsey L 2001 Function of cyclo-oxygenase-1 and cyclo-oxygenase- 2 in the ductus arteriosus from foetal lamb: differential development and change by oxygen and endotoxin. Br J Pharmacol 132:241-251

29. Loftin CD, Trivedi DB, Tiano HF, Clark JA, Lee CA, Epstein JA, Morham SG, Breyer MD, Nguyen M, Hawkins BM, Goulet JL, Smithies O, Koller BH, Langenbach R 2001 Failure of ductus arteriosus closure and remodeling in neonatal mice deficient in cyclooxygenase-1 and cyclooxygenase-2. Proc Natl Acad Sci U S A 98:1059-1064

30. Clyman RI 1987 Ductus arteriosus: current theories of prenatal and postnatal regulation. Semin Perinatol 11:64-71

31. Coceani F, Huhtanen D, Hamilton NC, Bishai I, Olley PM 1986 Involvement of intramural prostaglandin E2 in prenatal patency of the lamb ductus arteriosus. Can J Physiol Pharmacol 64:737-744

32. Coceani F, Kelsey L 1991 Endothelin-1 release from lamb ductus arteriosus: relevance to postnatal closure of the vessel. Can J Physiol Pharmacol 69:218-221

33. Bouayad A, Kajino H, Waleh N, Fouron JC, Andelfinger G, Varma DR, Skoll A, Vazquez A, Gobeil F Jr, Clyman RI, Chemtob S 2001 Characterization of PGE2 receptors in fetal and newborn lamb ductus arteriosus. Am J Physiol Heart Circ Physiol 280:H2342-H2349 